\title{
ON-FARM IRRIGATION RESERVOIRS IN TWO ARKANSAS CRITICAL GROUNDWATER REGIONS: A COMPARATIVE INVENTORY
}

\author{
M. A. Yaeger, M. L. Reba, J. H. Massey, M. A. A. Adviento-Borbe
}

\begin{abstract}
Arkansas, which ranks third in the nation in terms of irrigated cropland, relies heavily on the Mississippi River Valley alluvial aquifer for irrigation. Two critical groundwater areas have been identified, with one in the Grand Prairie in central Arkansas and the other along the Cache River in northeast Arkansas. Thus, there has been a call to develop surface water resources for irrigation, and as a result, on-farm irrigation reservoirs have been constructed to capture and store surface water. To assess the current state of surface water development, a remote-sensing survey using National Agricultural Imagery Program data was conducted to provide an inventory of the locations and surface area of on-farm reservoirs in the two critical groundwater areas. Expert consultation and on-site inspections were used to confirm the remote sensing results. In the larger Grand Prairie area, where aquifer decline was recognized earlier, 632 reservoirs were identified for a total surface area of 9,300 ha. In the Cache River area, 143 reservoirs were identified for a total surface area of 2,000 ha. Average reservoir size in both regions was $14.6 \pm 20$ ha and ranged from 1 to 265 ha. Reservoir area comprised approximately 3\% and $1 \%$ of the areas of potentially-irrigated cropland in Grand Prairie and Cache River regions, respectively.
\end{abstract}

Keywords. Aquifer depletion, Irrigation, On-farm reservoirs, Surface water.

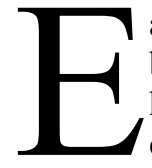
astern Arkansas, in the Lower Mississippi River basin, is a region of fertile soils and a mild, subhumid climate, making it ideal for agriculture. The clayey soils and flat floodplain slopes inhibit drainage, a characteristic suitable for growing rice (Oryza sativa). Thus rice is a major crop in eastern Arkansas, second only to soybean (Glycine $\max (L$.) Merr) in harvested area (USDA-NASS, 2015). In addition to rice and soybean, other major agronomic crops include corn (Zea mays L.), and cotton (Gossypium hirsutum) (USDA-NASS, 2015). While the soils characteristic of the region are highly productive agriculturally, many have poor water-holding capacities. This problem is worsened in many places by the presence of a shallow fragipan that limits rooting depth (Vories and Evett, 2014). Although the area receives over a meter of rain per year, precipitation varies seasonally. Peak rainfall mainly

\footnotetext{
(c) $(\$$ The authors have paid for open access for this article. This (c) ${ }_{\text {BY NG ND }}$ work is licensed under a Creative Commons AttributionNonCommercial-NoDerivatives 4.0 International License https://creative commons.org/licenses/by-nc-nd/4.0/

Submitted for review in March 2017 as manuscript number NRES 12352; approved for publication by the Natural Resources \& Environmental Systems Community of ASABE in October 2017.

Mention of company or trade names is for description only and does not imply endorsement by the USDA. The USDA is an equal opportunity provider and employer.

The authors are Mary A. Yaeger, Postdoctoral Researcher, Arkansas State University, East Jonesboro, Arkansas; Michele L. Reba, ASABE Member, Research Hydrologist, Joseph H. Massey, Research Agronomist, and M. Arlene A. Adviento-Borbe, Research Agronomist, USDA-ARS Delta Water Management Research Unit, Arkansas State University, East Jonesboro, Arkansas. Corresponding author: Mary A. Yaeger, 507 University Loop, East Jonesboro, AR 72401-0000; phone: 870680-4380; e-mail: myaeger@astate.edu.
}

occurs in winter and early spring, while the driest time of the year occurs in summer and early fall, coinciding with much of the crop growing season (Evett et al., 2003). In addition to these short-term droughts in the summer, the region has also periodically experienced severe drought years, notably in 1929, 1930, 1980, and 2012 (Gates, 2005; Tacker et al., 2010; Baker et al., 2012).

Underlying this region is the Mississippi River Valley Alluvial Aquifer (MRVAA) (fig. 1), a sand and gravel aquifer overlain in most parts by a confining clay layer of varying thickness (Renken, 1998; Hart et al., 2008). The hydrologic conductivity of the MRVAA ranges from 60 to $75 \mathrm{~m}^{\text {day }}{ }^{-1}$ west of the Crowley's Ridge outcrop (fig. 1), and decreases to the southwest, where it ranges from 30 to $60 \mathrm{~m} \mathrm{day}^{-1}$. The aquifer thickness also varies throughout the East Arkansas region, ranging from about 23 to $46 \mathrm{~m}$ thick in the north to 15 to $46 \mathrm{~m}$ thick in the west central portion. The thickness of the MRVAA in the northeast predominately ranges from 30 to $46 \mathrm{~m}$, except around the Crowley's Ridge outcrop, where it is 23 to $30 \mathrm{~m}$ thick, while in the southwest it is much more variable (Renken, 1998). There, the aquifer thickness is 30 to $46 \mathrm{~m}$ but thins towards the south, becoming 23 to $30 \mathrm{~m}$ thick, with some areas even thinner ( 15 to $23 \mathrm{~m}$ ). The confining unit is thinner in the northeast ( 3 to $12 \mathrm{~m}$ ) and thicker in the southwest (9 to $21 \mathrm{~m}$ ). Because of this confining layer, recharge to the Arkansas portion of the aquifer from surface water and precipitation is limited, occurring mainly where larger rivers have incised the confining layer or the layer itself is not present (Renken, 1998). An example of the former is the lower portion of the Arkansas River (fig. 1), as well as the lower White River which forms the eastern boundary of Arkansas County (fig. 1). Wells drilled 


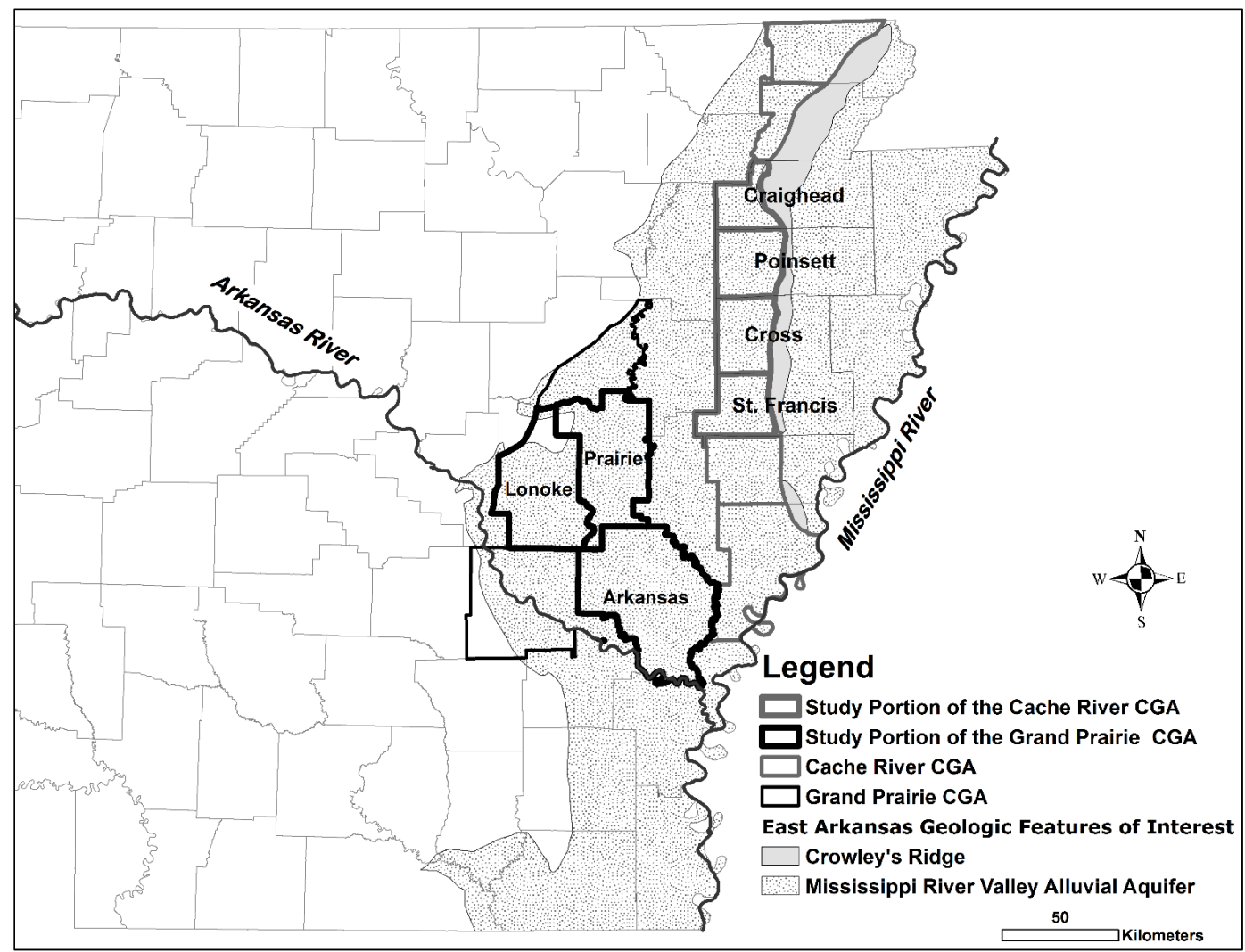

Figure 1. Mississippi River Valley Alluvial Aquifer and study regions in East Arkansas.

into this aquifer typically have produced, on average, 2,000 L min ${ }^{-1}$ (Renken, 1998) to 3,000 L min-1 (Czarnecki et al., 2002).

In this region, on average, a typical rice crop needs about $800 \mathrm{~mm}$ of water in a growing season (Robinson et al., 2003; Gates, 2005; Smith et al., 2007; Henry et al., 2016) while growing season precipitation can vary from 200 to $600 \mathrm{~mm}$ (Henry et al., 2016). Thus, the within-year rainfall variability of the region, coupled with the lack of water holding capacity of the soil and the production of rice, led to the adoption of irrigation early in the $20^{\text {th }}$ century (Gates, 2005; Vories and Evett, 2010). Since then, extensive development of irrigation in eastern Arkansas has been facilitated by the easily accessible MRVAA, a historically plentiful source of groundwater, and motivated by the need to reduce risk, especially after the severe drought of 1980 (Evett et al., 2003; Vories and Evett, 2014). At present, agriculture in the region relies heavily on groundwater-based irrigation (Clark et al., 2011; Marston et al., 2015), such that Arkansas ranks third in terms of irrigated cropland in the United States (USDANASS, 2014).

Aquifer depletion was recognized in the East Arkansas region as early as 1915, and officially since the 1930s (Gates, 2005; Vories and Evett, 2014), but solutions were not actively pursued until the 1980 s, when large portions of eastern Arkansas were designated as Groundwater Study Areas (ANRC, 2014a). Later, as the problem worsened due to expansion of irrigated agriculture and increased pumping, the designation was changed to Critical Groundwater Area (CGA). The Grand Prairie Groundwater Study Area encompasses Prairie, Lonoke, and Arkansas Counties (fig. 1) and became a CGA in 1998. The Cache River Groundwater Study Area, which includes Craighead, Poinsett, Cross, and St. Francis Counties west of Crowley's Ridge (fig. 1) received CGA status in 2009.

The present-day extent of the potentially irrigated land area in the Grand Prairie and Cache River regions is shown in figure 2a. Annual depth to groundwater measurements in wells monitored by the USGS throughout the region have shown a steady decline in water levels over time (Stanton et al., 1998; Schrader, 2001, 2006, 2008, 2010, 2015). As a result, two large cones of depression have formed, expanded, and persist in the aquifer beneath these two CGAs (Czarnecki, 2010; Clark, et al., 2011; ANRC, 2015). As shown in figure $2 \mathrm{~b}$, the deepest portions of the cones, where the depth to groundwater is 35 to $40 \mathrm{~m}$ from the land surface, are located in parts of Lonoke and Prairie Counties in the Grand Prairie CGA and in Poinsett County in the Cache River CGA. While these areas of the most severe aquifer depletion are not extremely large, persistent drawdown is widespread in both CGAs, as illustrated by the large areas where the depth to groundwater is greater than $20 \mathrm{~m}$ (fig. $2 \mathrm{~b}$ ).

Proposed solutions to help address the depletion of the MRVAA include better use of available rainfall and other surface water resources for irrigation. This approach features construction of on-farm reservoirs and tailwater recovery ditches for the capture and re-use of irrigation water (Gates, 2005; Prince-Czarnecki et al., 2016). There are also two large surface water diversion projects being jointly developed by the US Army Corps of Engineers (USACE) and USDA Natural Resources Conservation Service (USDA NRCS) in the Grand Prairie region (Robinson et al., 2003; 


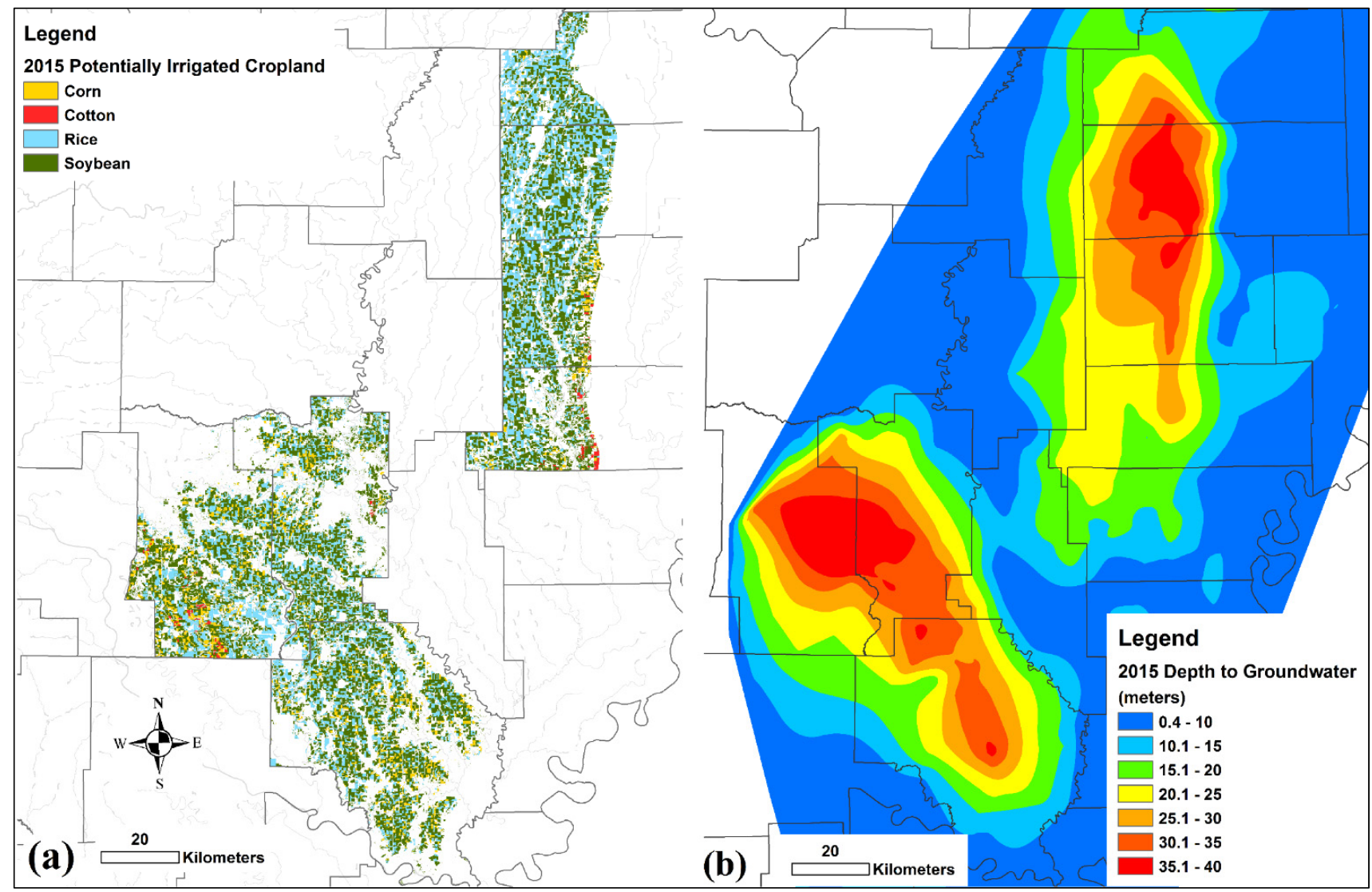

Figure 2. For 2015, (a) potentially irrigated cropland in Grand Prairie and Cache River areas and (b) depth to groundwater in the Mississippi River Valley Alluvial Aquifer.

Tacker et al., 2010). These irrigation projects, the Grand Prairie Area Demonstration Project and the Bayou Meto, will transfer water from the White and Arkansas Rivers, respectively, to on-farm storage reservoirs (ANRC, 2014b). Thus, surface reservoirs have been constructed independently by farmers or as part of the joint USACE-USDA NRCS projects for over 50 years (Gates, 2005; Prince-Czarnecki et al., 2016) and are expected to feature significantly in the productivity and economy of this diverse agricultural region.

Though the practice of implementing on-farm storage reservoirs is common in the region, there is a lack of information detailing the numbers and extent to which on-farm reservoirs have been developed in these CGAs. The USDA NRCS has assisted with funding for construction of more than 500 tailwater recovery systems in Arkansas (PrinceCzarnecki et al., 2016); however, these systems may or may not include an on-farm reservoir. Water planners and managers would benefit from accurate and timely knowledge of surface water resources to determine progress made in addressing aquifer decline and in assessing needs for future construction (Liebe et al., 2005; Rodrigues et al., 2012; Venkatesan et al., 2012). Therefore, a first step in this surface water resource assessment would be an inventory of on-farm irrigation reservoirs in the most critical regions of aquifer depletion. The objectives of this study, then, are to 1) identify and quantify the location and size, i.e. surface area, of current on-farm irrigation reservoirs in the two CGAs, and 2) relate this to aquifer characteristics of the location, i.e. depth to groundwater and saturated percent of aquifer thickness. In this way, the study will directly address the aforementioned lack of information about the number and locations of these surface-water resources, in relation to the groundwater cones of depression in the two CGAs.

\section{DATA AND METHODS}

A remote sensing inventory was carried out to obtain estimates of the number, surface area, and location of reservoirs present in 2015, the most recent year of imagery provided by the National Agricultural Imagery Program (NAIP). Depth to groundwater measurements from the USGS and aquifer thickness estimates from the Arkansas Natural Resource Commission (ANRC) were used to map areas of aquifer depletion and therefore relate reservoir locations to this characteristic.

\section{STUDY REGION}

The regions chosen as the focus of this study were subsets of the two CGAs in East Arkansas. The first study region included Prairie, Lonoke, and Arkansas Counties in the Grand Prairie CGA (bold black outline in fig. 1); the second included the portions of Craighead, Poinsett, Cross, and St. Francis Counties west of Crowley's Ridge (bold grey outline in fig. 1) in the Cache River CGA. The Grand Prairie study region is nearly 620,000 ha in size, with about half of that area in agricultural production, while the smaller Cache 
River study region encompasses almost 300,000 ha, with nearly $3 / 4$ of this area as cropland.

\section{DATA DESCRIPTION}

This study utilized county-level NAIP orthoimagery for the 2015 growing season, available from the USDA Geospatial Data Gateway (http://datagateway.nrcs.usda.gov). Leafon digital aerial imagery was available at the county scale as geo-referenced compressed mosaic images. The USDA Aerial Photography Field Office has specific standards for all NAIP images, ensuring that they were acquired at a $1-\mathrm{m}$ ground sample distance with a horizontal accuracy within $6 \mathrm{~m}$ of ground control points.

The recently updated Google Earth satellite imagery background from October 2015 in the Google Maps application (https://www.google.com/maps) was used in conjunction with the NAIP imagery because it provided sharper details when zoomed in, thus allowing for validation of features that may appear indistinct or pixelated in the NAIP images at that scale. Google Earth utilized data from multiple sources. These included high resolution, pan-sharpened images from LandSat 8 and DigitalGlobe satellites, and georeferenced aerial imagery from the USGS and USDA. Google imagery resolution varied from $15 \mathrm{~cm}$ to $15 \mathrm{~m}$ per pixel, depending on the source.

An interpolated groundwater surface map for 2015 was created from historical USGS well data available from the National Water Information System website (http://waterdata.usgs.gov/ar/nwis/uv/?referred_module $=\mathrm{gw}$ ) where measurements of the depth to groundwater for the Mississippi River Alluvial Aquifer were available as early as the 1930s. To avoid the influence of seasonal pumping on well data, the depth measurements for this study were chosen from the spring (February to June) of 2015 only (ANRC, 2015). The resulting discrete 433 well measurements were interpolated into a groundwater surface map in ArcGIS v.10.4, using the Natural Neighbor method (ESRI, 2016).

Because the severity of aquifer depletion is better described by combining estimates of aquifer thickness with the depth to groundwater to obtain the percent of aquifer thickness that is still saturated (ANRC 2015), modeled aquifer thickness estimates (Hart et al., 2008) were obtained from the ANRC for 220 wells within the same aquifer. These were then interpolated into a continuous surface map of aquifer thickness using the same Natural Neighbor method as previously described. The 433 well locations were overlaid on this interpolated surface to obtain estimates of aquifer thickness at each location. Depth to water measurements were subtracted from the aquifer thickness to obtain estimates of saturated thickness; the ratio of saturated thickness to aquifer thickness is then the saturated percent of aquifer thickness. The resulting discrete estimates of saturated percent of aquifer thickness were then interpolated into a continuous surface map using the Natural Neighbor method.

Cropland spatial data for 2015 were obtained from the USDA National Agricultural Statistics Service (NASS) CropScape website (https://nassgeodata.gmu.edu/CropScape). The cropland data layer (CDL) was provided in $30-\mathrm{m}$ resolution, with each $900-\mathrm{m}^{2}$ pixel assigned a land use or crop type value. According to the metadata that accompanied the CDL data, crop-specific pixels had a higher accuracy $(>80 \%)$ than non-crop pixels $(\sim 60 \%)$, since non-agricultural land cover in the CDL was based on the USGS 2011 Land Use/Land Cover data set. The accuracy of the major crop type pixels, e.g. soybean, rice, corn, and cotton, reported by the metadata was very high (94\% to $98 \%)$. Within each study region, land use pixels were sorted into crop and non-crop categories; the cropland category was then further sorted to separate all potentially irrigated cropland from the total cropland area. For this study, land under rice, corn, soybean, either single- or double-cropped following wheat (Triticum aestivum), and cotton was considered to be potentially irrigated. This refined cropland area was used because it more relevant to this study than total cropland area, as onfarm reservoirs are used to irrigate crops.

\section{RESERVOIR IDENTIFICATION}

Surface water bodies identified in the NAIP imagery were labeled as on-farm irrigation reservoirs if they possessed key surrounding features of a surface water irrigation system (Sullivan and Delp, 2012). These features included a tailwater recovery and irrigation regulating ditch, a supply/drainage pipe and/or pumping plant housing, and one or more adjacent crop fields (fig. 3a and 3b). Nearby sources of surface water such as a stream, ditch, or canal were also considered in the determination. In addition, surface water bodies whose primary function was not irrigation, but which may serve a secondary purpose as sources of irrigation water were identified by the survey, but not included in the reservoir inventory statistics reported here. These included road construction borrow pits (fig. 3c), lakes, and large reservoirs in natural regions or wildlife preserves.

The designation of a reservoir as an on-farm irrigation reservoir based on the NAIP imagery was verified by site visits, expert consultation (Tony Stevenson, USDA-NRCS and Deborah Leslie, USDA-ARS, personal communication, 2016), and the high resolution Google satellite imagery that was described earlier. On-farm reservoirs tend to be most full in the early spring, with drawdown occurring during the growing season as the stored water is used for irrigation (Sullivan and Delp, 2012). Since the Google Earth imagery in most of the study region was from the fall of 2015, the same year as the NAIP growing season imagery, this trend was useful in separating on-farm irrigation reservoirs from similar water bodies nearby whose main purpose was for waterfowl conservation and other uses (Tony Stevenson, USDANRCS, personal communication, 2016).

Once identified, a reservoir was then digitally delineated in ArcGIS v.10.4, and location (centroid latitude/longitude, county name) and size (surface area) were then calculated and tabulated for each reservoir polygon created. The process was repeated for each county NAIP county image in a CGA, for both CGAs, resulting in two individual spatial data layers, or shapefiles, and their associated database tables.

\section{RESERVOIRS AND GROUNDWATER}

Using the two reservoir polygon data layers, two point shapefiles were created of the centroid latitude/longitude of each reservoir. These layers were then superimposed on the 


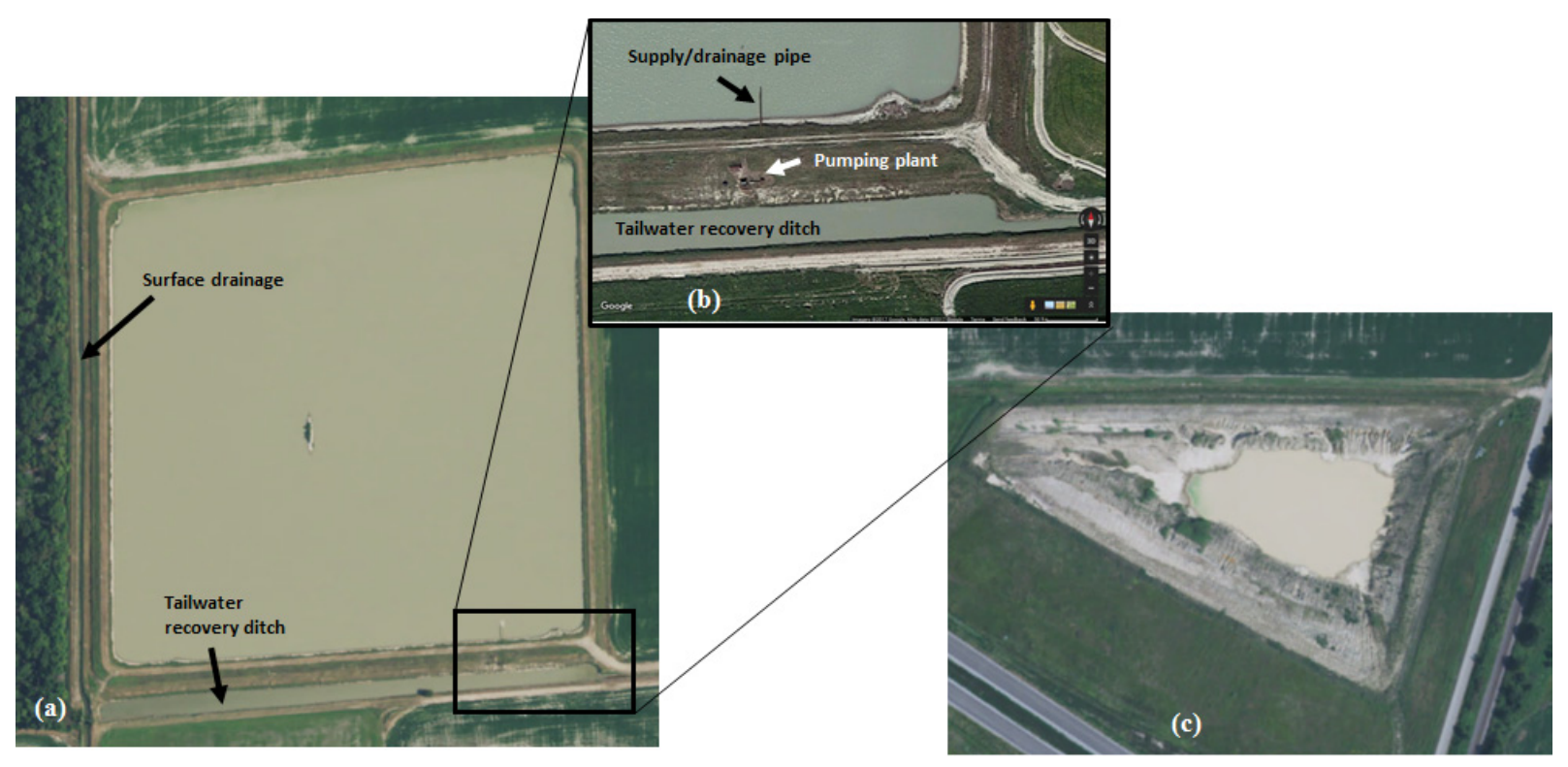

Figure 3. (a) NAIP orthoimagery of an on-farm reservoir and (b) Google Maps image detail of associated criteria. (c) NAIP orthoimagery of a surface water body that is not an on-farm reservoir.

Table 1. Inventory results for on-farm irrigation reservoirs existing in the Grand Prairie and Cache River critical groundwater regions of Arkansas in 2015.

\begin{tabular}{|c|c|c|c|c|c|c|c|c|c|}
\hline \multicolumn{5}{|c|}{ Grand Prairie Study Region } & \multicolumn{5}{|c|}{ Cache River Study Region } \\
\hline & \multirow{2}{*}{$\begin{array}{c}\text { Reservoir } \\
\text { Number }\end{array}$} & \multicolumn{3}{|c|}{ Surface Area (ha) } & & \multirow{2}{*}{$\begin{array}{c}\text { Reservoir } \\
\text { Number }\end{array}$} & \multicolumn{3}{|c|}{ Surface Area (ha) } \\
\hline & & Total & Average & Range & & & Total & Average & Range \\
\hline Prairie & 231 & 3,290 & 14.2 & 2 to 265 & Craighead & 36 & 665 & 18.5 & 1 to 125 \\
\hline Lonoke & 119 & 1,433 & 12.0 & 1 to 48 & Poinsett & 69 & 932 & 13.5 & 2 to 45 \\
\hline \multirow[t]{2}{*}{ Arkansas } & 282 & 4,613 & 16.4 & 2 to 217 & Cross & 24 & 232 & 9.7 & 2 to 35 \\
\hline & & & & & St. Francis & 14 & 190 & 13.6 & 3 to 38 \\
\hline Total & 632 & 9,336 & 14.8 & & Total & 143 & 2,019 & 14.1 & \\
\hline
\end{tabular}

interpolated depth to groundwater and then the percent saturated aquifer thickness surface layers to obtain estimates of each at the centroid of each reservoir location. Histograms were then produced using bin categories identified in the depth to groundwater and saturated aquifer thickness map creation steps.

\section{RESULTS}

\section{RESERVOIR INVENTORY - LOCATIONS AND SIZES}

Table 1 presents the inventory results and descriptive statistics of on-farm irrigation reservoirs in the study areas. Overall, the Grand Prairie CGA had close to four and a half times as many reservoirs and total reservoir surface area as the Cache River CGA. In the Grand Prairie CGA, 632 onfarm reservoirs were identified, with 282, 119, and 231 in Prairie, Lonoke, and Arkansas Counties, respectively. In the Cache River CGA, 143 on-farm reservoirs were identified, with 36, 69, 24, and 14 in Craighead, Poinsett, Cross, and St. Francis Counties, respectively. Reservoirs in Grand Prairie were clustered mainly in the northwestern portion of Arkansas County, southwestern Prairie County, and the central portion of Lonoke County (fig. 4). This corresponds to where the majority of soybean and rice have been grown in this CGA (fig. 2a). In the Cache River CGA, the majority of on-farm reservoirs were located throughout Poinsett County and in southern Craighead County. Here also, this corre- sponded to the location of intense rice and soybean cultivation (fig. 2a). However, Cross County immediately to the south was also dominated by rice and soybean agriculture, yet had fewer reservoirs than Craighead County.

Reservoir surface areas ranged in size from small (1 to $5 \mathrm{ha})$ to large ( $>100 \mathrm{ha})$ with the majority of reservoir sizes falling between 5 and 20 ha (fig. 5). In both CGAs the average surface area was approximately 14 ha, with the Grand Prairie average closer to 15 ha. In Grand Prairie, reservoir size distribution was consistent between the three counties, with the most common size being 5 to $10 \mathrm{ha}$, followed closely by 10 to 20 ha (fig. 6a). This consistency in surface area was not seen in the Cache River CGA; in Poinsett County 10 to 20 ha reservoirs were most common, followed by 5 to 10 ha, while in Craighead County small reservoirs ( 1 to 5 ha) were most common (fig. 7a). Cross and St. Francis Counties both had very few reservoirs, with the area distribution in Cross County similar to that of the Grand Prairie counties, while in St. Francis County 1 to 5 and 10 to 20 ha reservoirs were the most common. Craighead County was the only county in the Cache River CGA with reservoirs larger than 60 ha. In contrast, in the Grand Prairie CGA, Lonoke County was the only county with no reservoirs larger than 60 ha. However, in both regions, these larger reservoirs were a small proportion ( $3 \%$ or less) of the total number of reservoirs. Aside from cost and land availability, another possible reason could be that larger reservoirs are more susceptible to wind-driven wave erosion (Wren et al., 2016). 


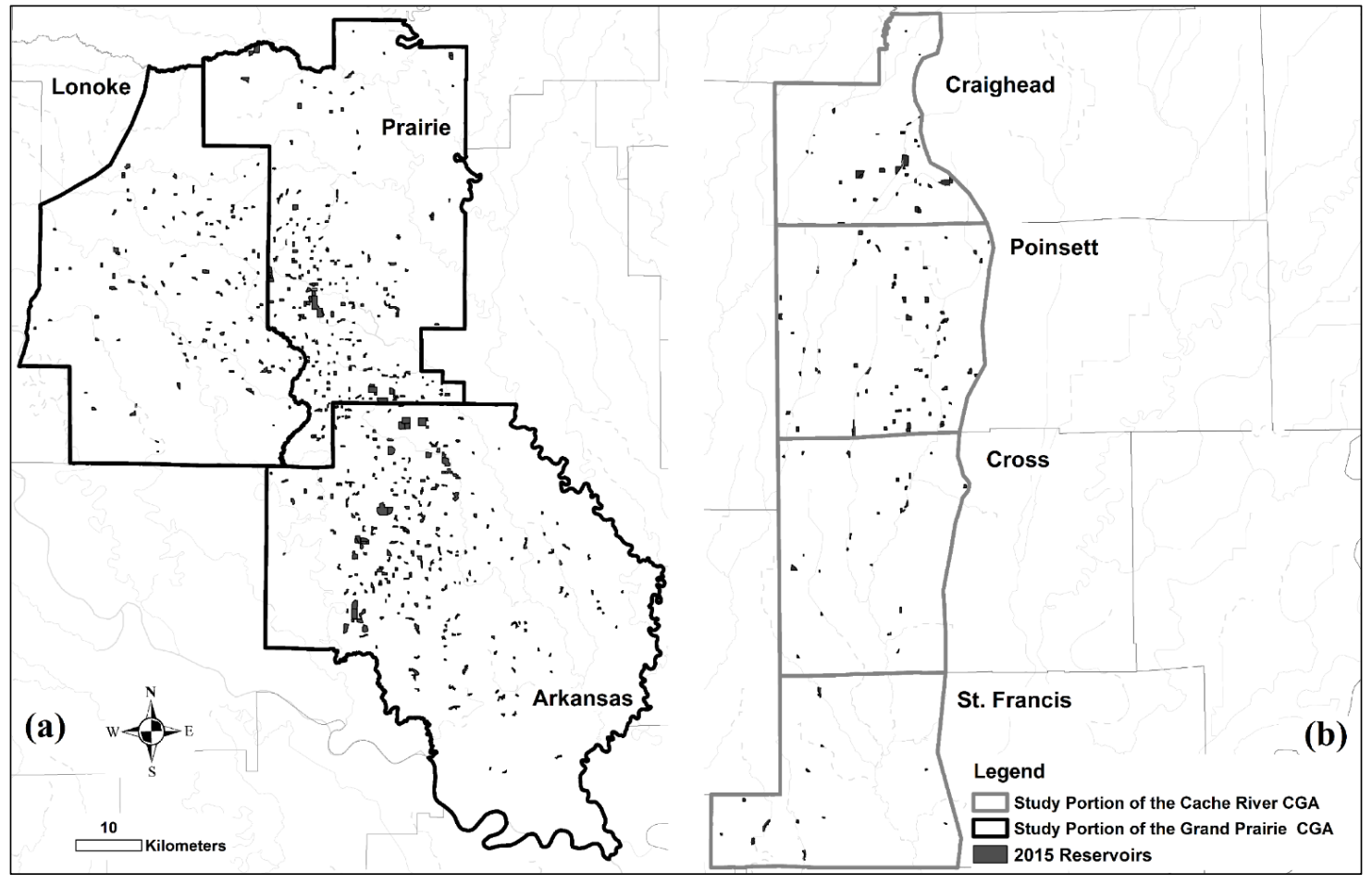

Figure 4. On-farm reservoirs in (a) Grand Prairie and (b) Cache River CGAs in 2015.

RESERVOIR LOCATIONS IN RELATION TO AQUIFER Characteristics

Exploration of reservoir distributions relative to aquifer characteristics of the location is presented in figures 5-7.
From the lumped distributions in figure 5, reservoirs were spread across a wide range of depths to groundwater, although they were a little more evenly distributed in Cache River than in Grand Prairie. There, reservoirs were more (a)
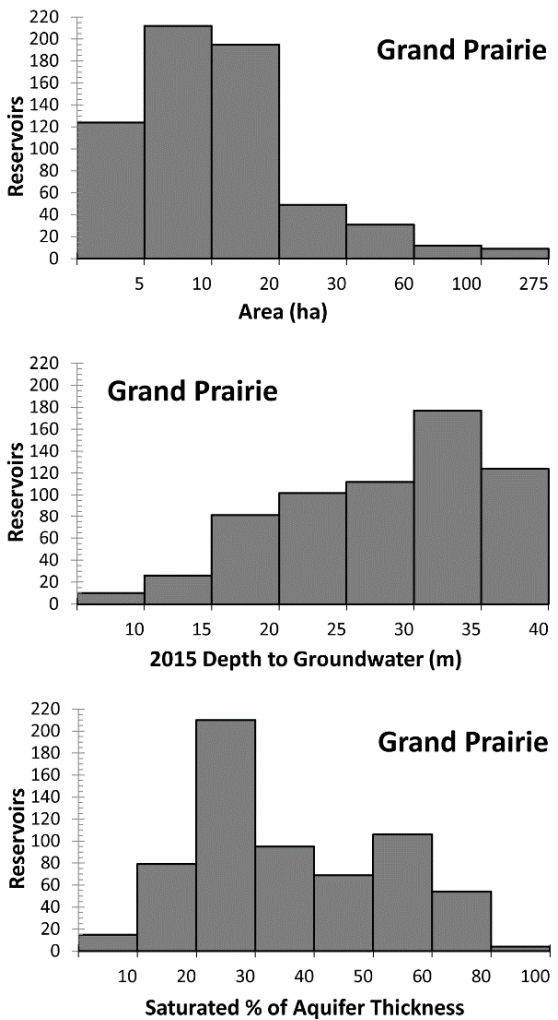

(b)
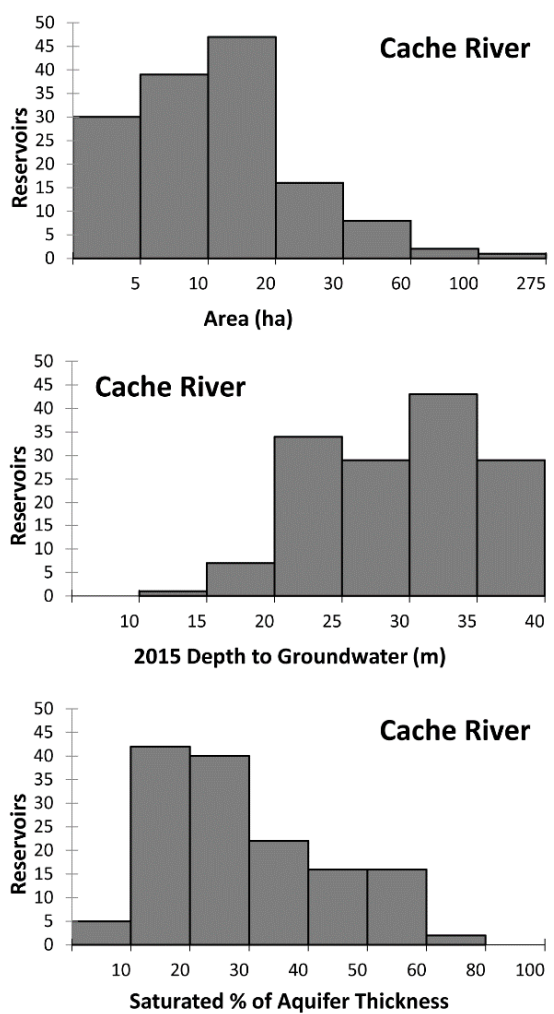

Figure 5. Lumped distributions of surface area, depth to groundwater, and percent saturated thickness for (a) Grand Prairie and (b) Cache River CGAs. 
(a)

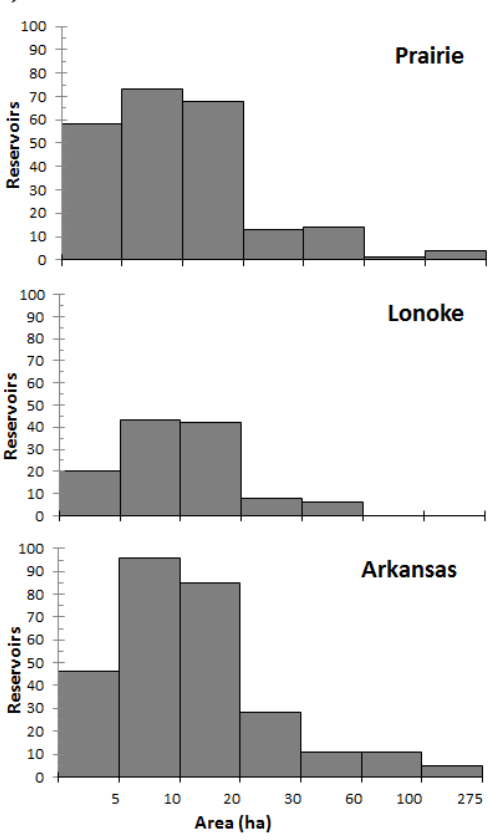

(b)
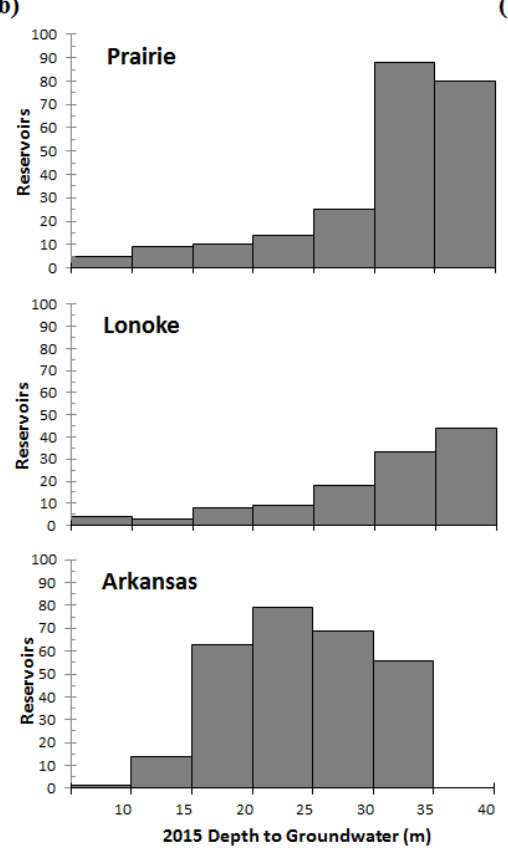

(c)

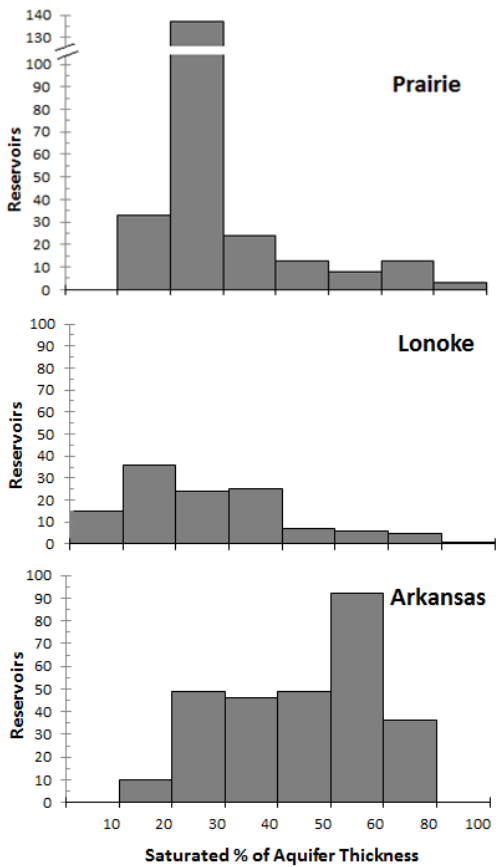

Figure 6. Distributions by county for (a) surface area, (b) depth to groundwater, and (c) percent saturated thickness for the Grand Prairie CGA.

concentrated where the depth to groundwater was 25 to $35 \mathrm{~m}$. By county, however, reservoir distributions varied in both regions (fig. 6b and 7b) with Prairie and Poinsett Counties having the most reservoirs over the deepest portions of the respective cones of depression. Since aquifer and confining layer thickness also varied between the CGAs, the distributions of reservoirs to saturated percent of aquifer thickness were different than those for depth to groundwater, even though the areas of severity were similar spatially for both depth to groundwater and saturated percent. For the latter case, in the Cache River CGA, the reservoirs were concentrated over areas of $10 \%$ to $30 \%$ saturation, while in the Grand Prairie CGA the vast majority of reservoirs were located over areas of $20 \%$ to $30 \%$ saturation (fig. 5). This was verified in the by-county distributions, where the trend was reflected in Prairie and Lonoke Counties in Grand Prairie (fig. 6c) and in Craighead and Poinsett Counties in Cache River (fig. 7c). This pattern was not seen in Arkansas County in Grand Prairie or in St. Francis County in Cache River, and for a similar reason in both cases. In those two counties, the majority of reservoirs were clustered over regions where $50 \%$ to $60 \%$ of the aquifer thickness was saturated. In Cross County in the Cache River CGA, the reservoir distribution was split, with most reservoirs clustered in areas where $20 \%$ to $30 \%$ of the aquifer remains saturated, as well as in areas where more than $40 \%$ to $50 \%$ of the aquifer is saturated.

\section{DiscuSSION}

\section{RESERVOIRS IN RELATION TO CROPLAND AND GROUNDWATER LEVELS}

The study area portion of the Grand Prairie CGA was a little more than twice the size of the study area portion of the Cache River CGA (table 2), but contained one and a half times as much total cropland area. Within each CGA, potentially irrigated cropland made up about $47 \%$ of the Grand Prairie study area, while in Cache River it was $68 \%$. The current amount of on-farm reservoir area was small when compared to the amount of land potentially receiving irrigation. In Grand Prairie, the total reservoir surface area was approximately $3 \%$ the size of the land area that may be irrigated; in Cache River, it was approximately $1 \%$. In both CGAs, soybean and rice together make up the vast majority of potentially irrigated cropland $-97 \%$ in Cache River and 90\% in Grand Prairie - but within each CGA the proportions of each crop are different. Taking this into account with the available reservoir surface area, the ratio of reservoir area to soybean and rice area in the Grand Prairie CGA was 5\% and $10 \%$, respectively, while in the Cache River CGA it was approximately $2 \%$ for both crops.

While cropland - and potentially irrigated cropland made up a larger percentage of the total area within the study portion of the Cache River CGA, the percentage of reservoir surface area relative to potentially irrigated area was one third that in Grand Prairie. However, aquifer drawdown was a more recent issue in Cache River compared to Grand Prairie. In both regions, the area where the depth to groundwater was greater than $25 \mathrm{~m}$ (fig. $2 \mathrm{~b}$ ) and where $30 \%$ or less of the aquifer thickness remained saturated spanned multiple counties. It is interesting to note that the density of potentially irrigated cropland in Cross County was similar to that in Poinsett and Craighead Counties (fig. 2a), while the depth to groundwater under much of this county was 25 to $40 \mathrm{~m}$ (fig. $2 \mathrm{~b}$ ) and the aquifer had about $10 \%$ to $40 \%$ saturated thickness remaining. Yet Cross County did not have nearly as many reservoirs as Craighead or Poinsett County. Factors such as underlying soils, geological features, annual rainfall amounts and patterns, etc. that normally could be used to ex- 

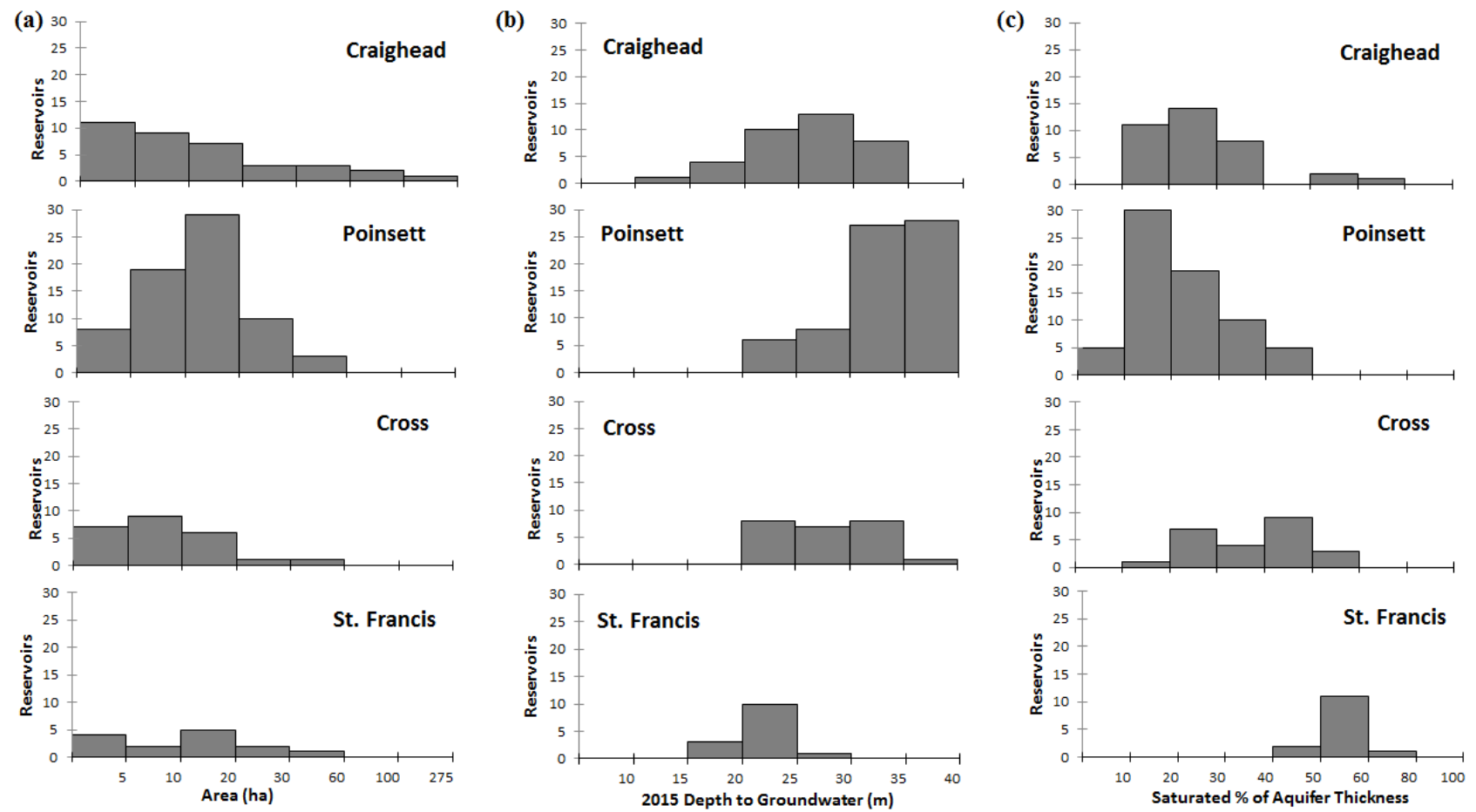

Figure 7. Distributions by county for (a) surface area, (b) depth to groundwater, and (c) percent saturated thickness for the Cache River CGA.

plain the development and distributions of on-farm reservoirs likely do not explain this discrepancy, since these are all very similar between the four counties in the Cache River study area. However, one possible explanation could be the size of the streams flowing in each county. The lower reaches of the L'Anguille River and the Bayou De View tributary of the Cache River flow through Cross County, while in Poinsett County are the middle and upper reaches of these two streams. Thus more surface water could be available for individual use in the larger reaches and tributaries of the L'Anguille and Bayou De View, possibly slowing or mitigating the need for development of on-farm irrigation reservoirs in Cross County.

\section{ESTIMATEd SERVICE AREAS OF RESERVOIRS EXISTING IN 2015}

From table 2, there were about 9,300 and 2,000 ha of onfarm reservoir surface area in the Grand Prairie and Cache River study areas, respectively. To place these values in context with the amount of farmland that could be potentially supplied with irrigation by these reservoirs, service ratios of 1:14 for the 148 White River Irrigation District (WRID) reservoirs in Grand Prairie, and 1:8 for all other reservoirs in

Table 2. Comparison of total on-farm reservoir surface area with cropland area in Grand Prairie and Cache River study regions in Arkansas.

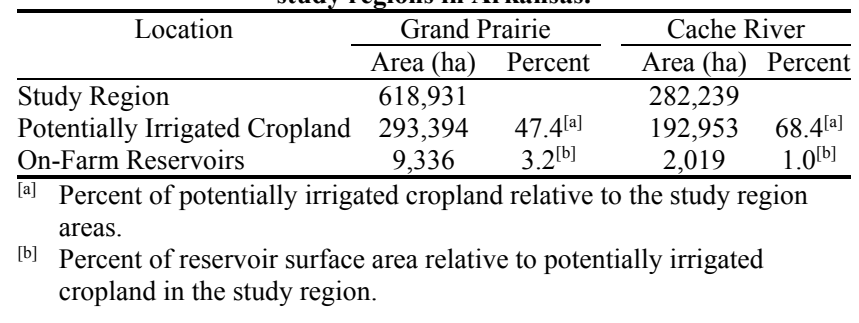

both regions were assumed (Walter Delp, USDA-NRCS, personal communication, 2017). These service ratios arose from the engineering designs and experience of the USDANRCS, which has assisted producers with the funding and construction of many of the reservoirs in Arkansas (PrinceCzarnecki et al., 2016), and thus incorporated general estimates of both reservoir storage capacity and crop consumptive use (Walter Delp and Charolette Bowie, USDA-NRCS, personal communication, 2017). Under these assumptions, a 10-ha reservoir could provide irrigation to 140-ha cropland in the WRID portion of the Grand Prairie study area, and 80 ha in the rest of the Grand Prairie and in the Cache River study areas. The reason for the different service ratios has to do with some reservoirs in Grand Prairie being filled both in winter, spring, and periodically throughout the growing season via surface diversion projects while those in the rest of the regions were generally only filled during winter-spring and might not be filled during the growing season. Thus, the 632 Grand Prairie reservoirs could be expected to provide irrigation to approximately 86,000 -ha cropland, while the 143 in Cache River could service about 16,000 ha. Actual areas serviced in a given year would depend upon prevailing weather conditions, crops grown, and irrigation practices and management styles used by producers.

\section{Current Water Projects AND POTENTIAL IMPLICATIONS}

The analyses of reservoir distributions in the two study CGAs suggested that surface water diversion projects influence not only the construction of on-farm reservoirs, but their size and location as well. Two large irrigation diversion projects are underway in the Grand Prairie CGA, and one, Plum Bayou in Lonoke County, has been completed (ANRC, 
2014b). These projects all have two components: on-farm reservoir construction and surface water resource development to supply them. While the surface water diversion portions of the projects are still under construction, approximately $1 / 3$ of the on-farm reservoir construction has been completed, and may partially explain the much greater number of reservoirs in Grand Prairie compared to Cache River. These surface water diversion projects could also explain the uniformity in the size distributions among all three counties in the Grand Prairie CGA, since there would likely be design specifications associated with project-driven reservoir construction. In the Cache River CGA, however, there are no major surface water diversion projects underway, and reservoir size distributions among the four counties here were more variable than those in the Grand Prairie. The influence of surface water diversion projects can also be seen in the locations of reservoirs in relation to aquifer cones of depression. In the Grand Prairie, less than half of the reservoirs (48\%) were located where the aquifer thickness was $\leq 30 \%$ saturated, and another sizeable percentage (26\%) were located where the aquifer saturated thickness was $\geq 60 \%$. In the Cache River area, more than half $(61 \%)$ of the reservoirs were located where the aquifer was $\leq 30 \%$ saturated, and only $13 \%$ of reservoirs were located in the less depleted areas, where the aquifer was $\geq 60 \%$ saturated. Because the surface water will be diverted from two large rivers, which are hydrologically connected to the aquifer, project reservoirs built closer to the diversion source would not be in the areas of most severe aquifer depletion.

Another potential implication of these results can be addressed by placing this reservoir inventory in a practical context, combining reservoir service areas with an estimate of total irrigated cropland to get an idea of how much of that land could be irrigated with surface water instead of groundwater. Using the most recent USDA census of irrigated agriculture, we estimated that $100 \%$ of rice was irrigated and $89 \%$ of soybean, $98 \%$ of maize, and $93 \%$ of cotton were irrigated at least once in these CGAs during the 2015 growing season (USDA-NASS, 2014). From the 2015 NASS CDL, as shown in figure $2 \mathrm{a}$, approximately 90,600 ha rice, and 203,000 ha soybean, maize, and cotton, combined, were grown in the Grand Prairie study region, for a total of 293,600 ha of potentially irrigated cropland. Similarly, 82,730 ha rice, and 110,220 ha soybean, maize, and cotton combined were grown in the Cache River study region, for a total of about 193,000 ha of potentially irrigated cropland. Thus, the portions of potentially-irrigated cropland that were irrigated would be approximately 273,000 ha in the Grand Prairie and 181,000 ha in the Cache River study regions. Given these assumptions, reservoirs existing in 2015 would be able to service approximately $32 \%$ and $9 \%$ of irrigated cropland in the Grand Prairie and Cache River study areas, respectively.

\section{Conclusions}

The results presented in this article represent a first step towards a needed surface water resource assessment. The objectives of this study were to quantify the number, size, and locations of current on-farm irrigation reservoirs in two CGAs, and relate these to the condition of the underlying aquifer. This was accomplished with a combination of remotely-sensed data and USGS well measurements. In areas with aquifer depletion and sufficient surface water for capture and storage, a regional inventory of on-farm irrigation reservoirs is a necessary component of sustainable watershed water resource planning, management, and research.

In summary, there were 775 on-farm irrigation reservoirs, for a total of about 11,300 ha in the two study regions in 2015. In the Grand Prairie CGA, 632 reservoirs were identified for a combined surface area of 9,300 ha, while in the Cache River CGA, 143 reservoirs were identified for a total surface area of 2,000 ha. A notable finding of this study was that compared to the Grand Prairie CGA, a higher percentage of the study area in the Cache River CGA potentially receives irrigation, but there is a smaller percentage of reservoir surface area that could supply it with water. One possible reason for this is that the issue of aquifer depletion is a more recent one in the Cache River CGA than in the Grand Prairie CGA. The Cache River area also benefits from a thicker aquifer, a thinner confining layer, and closer proximity to subsurface recharge from the northern, unconfined MRVAA in southeast Missouri and from the Ozark aquifer. This combination of factors may have contributed to the slower development of on-farm irrigation reservoirs in the Cache River CGA. Furthermore, unlike the Grand Prairie CGA, which is situated between the White and the Arkansas - two large rivers that could serve as additional surface water sources - the Cache River CGA lacks rivers with enough excess flow to supply large diversion projects (ANRC, 2014b). With $20 \%$ more potentially-irrigated cropland (relative to the total study region area) compared to the Grand Prairie, the Cache River CGA could benefit from concerted efforts to help producers capture and store more surface water for irrigation purposes.

More generally, the differences in reservoir distributions between the two critical groundwater regions showed the influence of large surface water diversion projects on reservoir construction and location. Because such projects would provide surface water supplements to rainfall capture, more reservoirs may be constructed, although smaller and more uniformly sized, and may be located across a wider range of aquifer depletion. With cost-sharing programs alone, fewer but more variably sized reservoirs may be constructed, and may likely be located in areas of greatest aquifer depletion.

\section{ACKNOWLEDGMENTS}

We gratefully acknowledge the technical assistance of $\mathrm{T}$. Stevenson (retired), W. Delp, and C. Bowie of the USDANRCS, and D. Carman, White River Irrigation District, for his development of the WRID reservoir database. All were essential to the quality assurance and validation of these findings. We also thank the associate editor and the anonymous reviewers for their comments and suggestions which have greatly improved this article. This project was funded in part by a Specific Cooperative Agreement between USDA-ARS and Arkansas State University. 


\section{REFERENCES}

ANRC. (2014a). Arkansas water plan: Update 2014. Little Rock: ANRC. Retrieved from http://arkansaswaterplan.org/plan/ArkansasWaterPlan/2014AW PWaterPlan/AWPFinalExecutiveSumm.pdf

ANRC. (2014b). Arkansas Water Plan 2014 Update Appendix G. Little Rock: ANRC. Retrieved from http://arkansaswaterplan.org/plan/ArkansasWaterPlan/2014AW PWaterPlan/App\%20G_2014\%2010\%2027\%20AWP\%20Final $\% 20$ Alternatives\%20Report.pdf

ANRC. (2015). Arkansas Groundwater Protection and Management Report for 2015. Little Rock: ANRC. Retrieved from https://static.ark.org/eeuploads/anrc/FINAL_DRAFT_ groundwater_rpt_2015-2016.pdf

Baker, J. M., Griffis, T. J., \& Ochsner, T. E. (2012). Coupling landscape water storage and supplemental irrigation to increase productivity and improve environmental stewardship in the U.S. Midwest. Water Resour. Res., 48(5), W05301. https://doi.org/10.1029/2011WR011780

Clark, B. R., Hart, R. M., \& Gurdak, J. (2011). Groundwater availability of the Mississippi embayment. Professional Paper 1785. Reston, VA: USGS.

Czarnecki, J. B. (2010). Groundwater-flow assessment of the Mississippi River Valley alluvial aquifer of northeastern Arkansas. Scientific Investigations Report 2010-5210. Reston, VA: USGS.

Czarnecki, J. B., Hays, P. D., \& McKee, P. W. (2002). The Mississippi River Valley alluvial aquifer in Arkansas: A sustainable water resource? Fact Sheet 041-02. Reston, VA: USGS.

ESRI. (2016). ArcGIS Desktop Support Online. Retrieved from http://desktop.arcgis.com

Evett, S., Carman, D., \& Bucks, D. (2003). Expansion of irrigation in the mid-south United States: Water allocation and research issues. Proc. 2nd Int. Conf. on Irrigation and Drainage. USCID.

Gates, J. (2005). Groundwater irrigation in the development of the Grand Prairie rice industry, 1896-1950. The Arkansas Historical Q., 64(4), 394-413. https://doi.org/10.2307/40023351

Hart, R. M., Clark, B. R., \& Bolyard, S. E. (2008). Digital surfaces and thicknesses of selected hydrogeologic units within the Mississippi Embayment Regional Aquifer Study (MERAS). Scientific Investigations Report 2008-5098. Reston, VA: USGS.

Henry, C. G., Hirsh, S. L., Anders, M. M., Vories, E. D., Reba, M. L., Watkins, K. B., \& Hardke, J. T. (2016). Annual irrigation water use for Arkansas rice production. J. Irrig. Drain Eng., 142(11), 05016006. https://doi.org/10.1061/(ASCE)IR.19434774.0001068

Liebe, J., van de Giesen, N., \& Andreini, M. (2005). Estimation of small reservoir storage capacities in a semi-arid environment: A case study in the Upper East Region of Ghana. Phys. Chem. Earth, 30(6-7), 448-454. https://doi.org/10.1016/j.pce.2005.06.011

Marston, L., Konar, M., Cai, X., \& Troy, T. J. (2015). Virtual groundwater transfers from overexploited aquifers in the United States. Proc. Natl. Acad. Sci., 112(28), 8561-8566. https://doi.org/10.1073/pnas.1500457112

Prince-Czarnecki, J. M., Omer, A. R., \& Dyer, J. L. (2016). Quantifying capture and use of tailwater recovery systems. $J$. Irrig. Drain. Eng., 143(1), 05016010. https://doi.org/10.1061/(ASCE)IR.1943-4774.0001124

Renken, R. A. (1998). Ground water atlas of the United States: Segment 5, Arkansas, Louisiana, Mississippi. Hydrologic Investigations Atlas 730-F. Reston, VA: USGS.
Robinson, P., Clemmens, A. J., Carman, D. K., Dalmut, Z., \& Fortner, T. (2003). Irrigation development in eastern Arkansas: Water supplies, uses, and efficiencies. Proc. 2nd Int. Conf. on Irrigation and Drainage. USCID.

Rodrigues, L. N., Sano, E. E., Steenhuis, T. S., \& Passo, D.1. P. (2012). Estimation of small reservoir storage capacities with remote sensing in the Brazilian Savannah region. Water Resour. Manag., 26(4), 873-882. https://doi.org/10.1007/s11269-0119941-8

Schrader, T. P. (2001). Status of water levels and selected waterquality conditions in the Mississippi River Valley alluvial aquifer in eastern Arkansas, 2000. Water-Resources Investigations Report 01-4124. Reston, VA: USGS.

Schrader, T. P. (2006). Status of water levels and selected waterquality conditions in the Mississippi River Valley alluvial aquifer in eastern Arkansas, 2004. Scientific Investigations Report 2006-5128. Reston, VA: USGS.

Schrader, T. P. (2008). Water levels and selected water-quality conditions in the Mississippi River Valley alluvial aquifer in eastern Arkansas, 2006. Scientific Investigations Report 20085092. Reston, VA: USGS.

Schrader, T. P. (2010). Water levels and selected water-quality conditions in the Mississippi River Valley alluvial aquifer in eastern Arkansas, 2008. Scientific Investigations Report 20105140. Reston, VA: USGS.

Schrader, T. P. (2015). Water levels and water quality in the Mississippi River Valley alluvial aquifer in eastern Arkansas, 2012. Scientific Investigations Report 2015-5059. Reston, VA: USGS. https://doi.org/10.3133/sir20155059

Smith, M. C., Massey, J. H., Branson, J., Epting, J. W., Pennington, D., Tacker, P. L.,... Wilson, C. (2007). Water use estimates for various rice production systems in Mississippi and Arkansas. Irrig. Sci., 25(2), 141-147. https://doi.org/10.1007/s00271-0060041-0

Stanton, G. P., Joseph, R. L., \& Pugh, A. L. (1998). Status of water levels and selected water-quality conditions in the Mississippi River Valley alluvial aquifer in eastern Arkansas, 1994-1996. Water-Resources Investigations Report 98-4131. Reston, VA: USGS.

Sullivan, M. E., \& Delp, W. M. (2012). Water conservation planning: How a systems approach to irrigation promotes sustainable water use. NABC Report 24: Water Sustainability in Agriculture. 145-159. Washington, DC: USDA-NRCS.

Tacker, P., Vories, E., \& Carman, D. (2010). Water supply problems and solutions in the Grand Prairie region of Arkansas. ASABE Paper No. IRR10-9844. St. Joseph, MI: ASABE.

USDA-NASS. (2014). 2012 Census of Agriculture, Farm and Ranch Irrigation Survey (2013), Vol. 3, Special Studies, Part 1. Washington, DC: USDA-NASS.

USDA-NASS. (2015). Acreage. Washington, DC: USDA-NASS. Retrieved from

http://usda.mannlib.cornell.edu/usda/nass/Acre//2010s/2015/Acr e-06-30-2015.pdf

Venkatesan, V., Balamurugan, R., \& Krishnaveni, M. (2012). Establishing water surface area-storage capacity relationship of small tanks using SRTM and GPS. Energy Procedia, 16, 11671173. https://doi.org/10.1016/j.egypro.2012.01.186

Vories, E. D., \& Evett, S. R. (2010). Irrigation research needs in the USA Mid-South and Southeast, humid and sub-humid regions. ASABE Paper No. IRR10-8679. St. Joseph, MI: ASABE.

Vories, E. D., \& Evett, S. R. (2014). Irrigation challenges in the sub-humid US Mid-South. Int. J. of Water, 8(3), 259-274. https://doi.org/10.1504/IJW.2014.064220

Wren, D., Ozeren, Y., \& Reba, M. (2016). Measuring the erosion of an irrigation reservoir levee. Trans. ASABE, 59(1), 41-48. https://doi.org/10.13031/trans.59.10751 